\title{
Jair Bolsonaro and the Dominant Counterpublicity
}

\author{
Camila Rocha ${ }^{1}$ \\ https://orcid.org/0000-0001-8291-9149 \\ Jonas Medeiros ${ }^{2}$ \\ https://orcid.org/0000-0002-7021-8393 \\ ${ }^{1}$ Universidade de São Paulo, São Paulo/SP, Brazil \\ ${ }^{2}$ Centro Brasileiro de Análise e Planejamento, São Paulo/SP, Brazil
}

This article focuses on the controversial and infamous behavior of Brazilian President Jair Bolsonaro in the public sphere. Based on an understanding that there exists something specific in relation to his strategy of rhetorical mobilization and the discursive domination related to broader dynamics in the Brazilian public sphere, we seek to analyze here the use of what we consider to be a 'dominant counterpublicity'.

Keywords: Extreme right; counterpublics; public sphere; Jair Bolsonaro.

http://doi.org/10.1590/1981-3821202100030004

Correspondence: Camila Rocha. Email: camilarocha44@gmail.com

This publication is registered under a CC-BY Licence. 
$\mathrm{P}$

rogressive sectors of Brazilian society have accompanied with horror the polemical declarations of Jair Bolsonaro and his followers, as well as the dissemination in the public debate of ideas related to a positive revaluation of the monarchy (overthrown in 1889) and the military dictatorship established in 1964, or even the refuse to pay taxes, 'gender ideology', and 'globalism'. To understand how determined ideas, which had previously circulated only in restricted circles, became routine in public debate, it is fundamental to take into account the contemporary dynamics which pervade the public sphere, especially the proliferation of 'counterpublics'.

This article focuses on the controversial and infamous behavior of Jair Bolsonaro in the public sphere. Based on an understanding that there exists something specific in relation to his strategy of rhetorical mobilization and the discursive domination related to broader dynamics in the Brazilian public sphere, we seek to analyze here the use of what we consider to be a 'dominant counterpublicity'. A paradoxical phenomenon which challenges our understandings.

In the first section of the article we make a brief review on the postHabermasian debate on the public sphere, which produced studies on publics and counterpublics. In the second section we analyze the use of right-wing counterpublicity in Brazil, and, finally, in the third section, we show how the behavior of Bolsonaro and his supporters in the public sphere can be interpreted based on the idea of a dominant counterpublicity and the implications of this discursive strategy for democratic coexistence.

\section{The post-Habermasian debate: publics and counterpublics}

The concept of counterpublic was originally developed with the purpose of highlighting supposed insufficiencies in the reflections of the German philosopher Jürgen Habermas (1989) in relation to the democratizing potential of the public sphere (FRASER, 1997). Habermas (1989) was criticized for idealizing the public sphere as a social space in which there occurred only rational public debates and also for ignoring how determined social groups are excluded, to a greater or lesser extent, from the public arena. In this sense, the use of the concept of counterpublic is not related here to his classic conception of public sphere, but rather to the post-Habermasian turn of 'Counterpublic Studies'. 
To analyze the contemporary dynamics of the public sphere, first of all, it is necessary to bear in mind the idea that there does not exist anything like a unified public sphere, but rather a multiplicity of 'publics'. Publics are formed through the reflexive circulation of texts, photos, videos, performances, and other discursive media $^{1}$ and can be more or less local, more or less integrated, more or less official and institutionalized, and more or less digitalized (CELIKATES, 2015). In this way, there are publics which are dominant - in general those who are closer to state, capital, and science - and publics which occupy a subordinated position in relation to the former.

What all the publics possess in common is the fact that they are voluntary, self-organized spaces, aimed at sociability among strangers, in other words, the formation of ties between people who do not know each other 'a priori'. Participating in these publics thus requires a minimum of attention, as well as a shared understanding, that their arguments should be based on a rational-critical reflection, an understanding which acts as a type of predominant ideology in dominant publics. This occurs because although discursive modes and ways of addressing of a performative nature are present to some degree in any public, a rational-critical approach possesses a greater legitimacy to the extent that it allows a more effective interlocution with the state (WARNER, 2002).

However, it has to be remembered that relations of domination in the public sphere are not static. There are publics which have greater decision making power in society (strong publics) and publics with lower decision-making power (weak publics), while the publics with the greatest decision-making power at a given moment can be understood as dominant publics. This occurs when a public is capable of naturalizing its own cultural horizon through the diffusion and perpetuation of its own codes, performances, ideas, and structures, which have come to be understood as consensual. This process is consolidated to the extent that these publics obtain success in legitimating their discourses and practices in central discursive arenas, related to the state, the market, and science. Nevertheless, these relations of domination and hegemony are dynamic, since marginal and weak publics with little hegemonic potential can conquer greater power and legitimacy

${ }^{1}$ We start with the reflection of Michael Warner (2002), though we will expand this analysis of the twenty-first century public sphere beyond written culture. 
over time, while dominant publics can lose their legitimacy and potential influence, making them marginal and weak publics. An example of this are the defenders of monarchy in Brazil, who became marginal and minoritarian after the establishment of the republic; another example are the anti-communists and defenders of the legacy of the Brazilian civil-military dictatorship (1964-1985), who also experienced an important decline in power and legitimacy in the public sphere shortly after redemocratization.

However, while on the one hand there are publics who aim to obtain legitimacy from the state, the market, or science, on the other hand there also those who go in the opposite direction. With the explicit purpose of attacking the state and the established order, these publics seek to put into circulation texts of opposition to a cultural horizon perceived as dominant and whose performative nature stands out, causing reactions of shock and disturbance of the social order. As they consciously disobey the rules of decorum instituted by dominant publics, these publics are better understood as 'counterpublics' (WARNER, 2002).

This struggle against determined world-views that predominate in dominant publics occurs through a disruptive and shocking form of addressing that is called 'counterpublicity'. It is precisely the appeal to counterpublicity which differentiates counterpublics from other publics. In this sense, what is decisive here is the 'shared perception' among the members of counterpublics that they are facing a culturally dominant horizon. In their members' understanding, the fact that dominant publics are structured through relations of domination limits the scope of rational-critical discourses in these arenas, which motivates the employment of a 'shock politics' (ROCHA and MEDEIROS, 2020) to call the attention of society to these relations of domination. What unites the members of any counterpublic is, thus, the shared perception that their world-views are subordinated to a dominant cultural horizon which alienates, silences, attacks, disparages, and even ridicules them; hence their appeal to counterpublicity.

Initially the concept of counterpublic was employed to understand the action of subaltern social groups in the public sphere, but recently it also came to be used to understand the rise of groups and leaders located on the right of the political spectrum (DOWNEY and FENTON, 2003; THIMSEN, 2017), as we will do here. While for the members of 'queer' counterpublics, who oriented the pioneering 
theorization about counterpublicity by the literary critic Michael Warner (2002), heteronormativity is hegemonic in dominant publics, for the purposes of the analysis proposed here, a determined discourse can also be read as hegemonic by members of right-wing counterpublics. In this sense, it is not relevant if, for example, 'globalism' - progressive elites who act with the aim of transnational governance (CARVALHO, 2009) - actually corresponds to an objective reality or not, what matters is that, according to the perception shared by members of anti-globalism counterpublics, globalists are hegemonic in dominant publics, such as the mainstream media, academia, and international organizations (ARAÚJO, 2021).

However, although the use of counterpublicity is common among all counterpublics, both on the left and on the right, there exists an important distinction in relation to the subalternity of those who use it. The qualification of subaltern and non-subaltern is related to the dominant or dominated social position within systems of oppression - such as class, race, gender, and sexuality (COLLINS, 2009) -, considering that subalternity necessarily possesses both a structural/objective aspect and a symbolic/subjective aspect ${ }^{2}$.

In this way, anti-globalist women can constitute a counterpublic, but they should not be seen as a subaltern counterpublic just because they are women. After all, these women probably do not perceive themselves as dominated in a social structure which privileges men, or do not do so in a central form, but rather see themselves as culturally subordinated by dominant publics regarded as globalists. Similarly, right-wing homosexuals can also belong to a non-subaltern counterpublic, since these do not see themselves as dominated by a heteronormative social structure, even though this structure objectively exists and inspires murders for motives as banal as the panic caused by a boy with a way of walking deemed to be effeminate (BUTLER, 2006).

Taking this into account, it is possible to sketch out here a typology of publics and counterpublics. In first place there is a distinction between dominant and marginal publics. Among the latter there are marginal and subaltern publics, such as feminist activists who act as members of subaltern publics in poor neighborhood

\footnotetext{
${ }^{2}$ Hill Collins (2009) calls the first aspect the "structural domain of power" (the organization of oppression, in other words the unequal and unjust distribution of socially valued resources) and the second the "hegemonic domain of power" (representations which legitimate and justify oppression or then question it in a counter-hegemonic form).
} 
associations and make use only of a rational-critical discursive approach to demand more childcare facilities or more public facilities for victims of domestic violence (MEDEIROS, 2017). On the other hand, SlutWalk activists who expose their breasts in public to call attention to feminist causes, would be members of subaltern counterpublics (GOMES, 2018; MEDEIROS and FANTI, 2019). Similarly, it is also possible to understand defenders of monarchy or the unrestricted privatization of the economy who defend their agendas through rational-critical arguments as marginal non-subaltern publics; and right-wing groups and political actors who make disruptive and shocking discourses and performances as right-wing counterpublics, whom we shall analyze next.

\section{Right-wing counterpublics}

Before Jair Bolsonaro was elected, a new right had emerged in the country. While the traditional right did not assume itself as such due to the stigma of having participated in the military dictatorship and became known as an 'ashamed right' (POWER, 2010) a new right emerged during the Lula Administration (2003-2010): shameless and more radical. Based on the idea proposed by the philosopher Olavo de Carvalho that there is a 'left-wing cultural hegemony', this new right adopted a contra-hegemonic strategy. With a rhetoric marked by aggressiveness, lack of decorum, and shock-based politics, the emerging new right promulgated an ultraliberal and conservative ideal, centered above all on a Libertarian appropriation of the work of Ludwig von Mises, that was disseminated, mainly in social media which permitted the encounter and debate between people who felt marginalized and despised in the public sphere (ROCHA, 2021).

At that time the internet came to function as a refuge for right-wing groups or simply for those who did not feel represented by the Workers Party government. Feeling excluded from dominant publics, these people discovered on the Internet the possibility of finding others with whom they could exchange ideas and solidarize with through forums, blogs, and sites. In this sense, the emergence of the social media Orkut, founded in 2004, was especially important, since it ended up becoming the most important media for the rise of the Brazilian new right.

The first step in this direction was taken at the end of the 1990s, with the creation of a blog by the philosopher Olavo de Carvalho in 1998 entitled 'Sapientiam 
autem non vincit malitia' (Wisdom is not defeated by malice). Years after, together with other critics of the Brazilian left, in 2002 Carvalho created a site called 'Media Without a Mask', which disseminated texts by various authors about politics, the economy, and philosophy, and soon became well known among Brazilians who frequented internet forums, so when Orkut was founded, in 2004, it was already possible to find two forums of readers and admirers of Olavo de Carvalho's work: "Olavo de Carvalho" and "The Philosophy of Olavo de Carvalho", as well as two formed by his mockers and haters, "Olavo de Carvalho hates us" and "I hate Olavo de Carvalho" (ROCHA, 2018).

Initially aimed at a US public, Orkut became popular so quickly in Brazil that in January 2006, around 75\% of its users came from the country (FRAGOSO, 2006), signaling a precocious engagement of Brazilian users in comparison with people of other nationalities. However, the record number of Brazilians did not mean that access to Orkut was homogenous among the population as a whole. Between 2005 and 2007, when Orkut was the most popular social media in Brazil, access to the internet in the country was mainly restricted to teenagers and young adults with high levels of income and education, located mostly in the Southeast and South regions, who had computers at home and/or frequented paid access centers such as internet cafes $^{3}$, to communicate, look for information, or as a source of leisure; activities which were all provided by Orkut.

In Orkut it was possible to create forums about the most diverse subjects, however, the use of fake profiles and anonymous accounts was quite common, which contributed to very free and at times violent atmosphere (FRAGOSO, 2006); something analogous to what Angela Nagle (2017) describes regarding the US altright digital forums. The ambience of widespread freedom provided by Orkut attracted exactly those people who did not feel represented in the debates that occurred in dominant publics; and even those who did not feel represented in debates within Orkut itself could create their own forums, as the philosophy teacher Marcus Boeira did. Boeira, then a graduate student in law who had been a student of Olavo de Carvalho in an face-to-face course in Porto Alegre at the beginning of the

\footnotetext{
${ }^{3}$ This and other more detailed information about access to the Internet in Brazil were published by the Brazilian Internet Steering Committee (CGI.br) and can consulted at <http://www.cetic.br/media/docs/publicacoes/10/pal2007ofid-11.pdf>.
} 
2000s: "At that time, it seemed to me that there was a stronger Gramscian hegemony than today. We now have a greater pulverization, but at that time no, it was very difficult. There were around 20 people in these environments, and the rest, practically ninety-something percent, were saying the same" (ROCHA, 2021, p. 11).

The 'Gramscian hegemony' refers to Olavo de Carvalho's ideas about a Gramscian revolution led by intellectuals of the left and the PT. Over time this argument was spread through the internet to a broader public, and a simplified version of it ended up becoming the cornerstone of the discourse of the new right. According to Boeira, there existed three main groups of Orkut users who circulated in forums dedicated to the positive appreciation of the work of Olavo de Carvalho: 01. a majoritarian group ranging from anarcho-capitalists to neoliberals, who consistently took positions against the left, primarily based on a critique regarding a 'more market vs. more state' formula; 02. a more dispersed group formed by advocates of more conservative agendas, and here it is possible to include defenders of the monarchy and the military regime; and 03. a Catholic public which was a minority and less participative in comparison with the other two groups. Despite their differences, what brought together these people in the Olavo de Carvalho forums was, above all, the feeling of not being represented in dominant publics, whose discourses are based on the prerogatives established by the 1988 constitutional pact, which were perceived, in accordance with the ideas defended by Carvalho, as being hegemonized by the left. As Boeira notes: "He would say what everyone would like to say to journalists, university professors, people from the mainstream media, people from NGOs, etc. He said everything that many people wanted to say and who did not have a voice. He channeled all these voices (...) which were spread all over Brazil but were not connected" (ROCHA, 2021, p. 11).

Boeira's perception of the isolation and lack of representation of right-wing people in dominant publics at the time, related to academia, in the field of the human sciences, book publishers, and the traditional media, was shared by many of these forums' users. To call attention to their ideas, it was very common the use of the use of caustic and shocking language as well as curse words was very common. Quite illustrative of this is Olavo de Carvalho's discourse in the final 
episode of his podcast True Outspeak (active between 2006 and 2012), justifying it's ending:

\begin{abstract}
I believe that it [the podcast] has achieved its goals and from now on I will only be repeating what was already said. One of these goals was to modify a bit the language of political talk in Brazil. Because to the extent that the conduct of our politicians descended to appalling levels it didn't make any sense to continue to speak of them using polite language, the educated language used by the opposition. We have to learn to say that a 'motherfucker' is a 'motherfucker' and so on. Even because this is their language, this is the language of Mr. Lula! Mr. Lula is always cursing, now if we curse, they [say] 'Ah, how rude'. We had to lower our standards. We have done so. To do this, I had to make this concession of speaking the language of Brazilian 'trash talk', which is not my language. However, it is the only way of making people realize the horrible mess which Brazil has become. And create a language, which is this bad language, to actually talk about it. This purpose has been entirely fulfilled. I see that many people have learned this. They learned to curse, they learned to tell someone to shove it up your ass because they needed to shove it up in the ass, they learned to call someone a motherfucker when they had to be called 'motherfucker' and so on. And I think this is a huge progress! (CARVALHO, 2012, podcast).
\end{abstract}

Shock politics, as mentioned above, is frequently used in a conscious form as a radical counter-hegemonic strategy when there exists a perception on the part of members of determined publics that their ideas do not circulate in dominant publics, and that the actual manifestation of their world-views and the ways of life they defend are under imminent threat. Over time, this perception came to be shared with political actors of the far-right, such as Jair Bolsonaro and his sons. During a 'live'4 with Olavo de Carvalho, also in 2012, when the Tiradentes Medal was delivered to him, an honor granted by the State Assembly of Rio de Janeiro to the writer, Flávio Bolsonaro (2012), then a state deputy, stated:

I have a different way of seeing things, and because of that, I do not have any space in the press. There are those people who criticize us and certainly also criticize you, Olavo, because of the way you act in a discussion. But I believe it is necessary to create the fact, to call attention, to 'shock', especially considering certain issues, so they can receive some attention from the press and the population as a whole can gain access to this discussion, like the famous 'gay kit'. If Deputy Jair Bolsonaro did not call attention to this issue in an ostensive manner, we would never

\footnotetext{
${ }^{4}$ The video can be seen on the YouTube channels of Flávio Bolsonaro (Available at <https://www.youtube.com/watch?v=Cb0JGA80iLo>) or Mídia Sem Máscara [Media Without a Mask] (Available at <https://www.youtube.com/watch?v=q5S47UfPF1g>).
} 
know there was this incentive to sexuality, whether on the "homosexual side' or the 'heterosexual side' (sic), Olavo, for children of six years of age, for now in public schools, but we do not know what the next step will be, it can affect private schools too, because I am certain that the middle and upper classes will also engage in this discussion.

(Olavo de Carvalho in response): They want to create a clientele for the pedophiles, who doesn't get this? (BOLSONARO, 2012) (emphasis added).

Indeed, between 2011 and 2014, Brazil went through what was felt by conservative sectors as a 'shock of progressivism'. In 2011 the National Truth Commission (Comissão Nacional da Verdade - CNV) was created to investigate the crimes committed by the state during the military dictatorship, while in the same year, the Federal Supreme Court (STF) recognized stable same-sex unions. In the following years, the same court also recognized the right to abortion in cases of fetal anencephaly and the racial quota system in public universities. In 2013 a bill called 'PEC das Domésticas' was enacted, which expanded the labor rights of domestic workers, while in 2014, another bill popularized as the 'Slapping Law', which prohibited the use of physical punishment and cruel and degrading treatment of children and adolescents, was also enacted.

Given this scenario, as Flávio Bolsonaro (2012) pointed out, his father, did not hesitate in taking the lead in the reaction to such progressive measures. Along with other conservative Congresspeople, Jair Bolsonaro managed to stop the printing of school material related to the 'School Without Homophobia' project, related to the 'Brazil Without Homophobia' program, drafted in 2004, and pejoratively called the 'Gay Kit'. However, he did not have the same success concerning the CNV and the approval of stable same-sex unions, which were regulated by the National Council of Justice in May 2013.

During the same period, in addition to the reaction of conservative Congresspeople, the dissemination of the manifestations of determined counterpublics, on the left and the right, increased. This occurred above all due to the conjunction of a growing political polarization with the popularization of the internet in the country 5 , which increased exponentially the potential scope of alternative individuals and groups, as was the case of the Brazilian Slut Walks.

\footnotetext{
5In relation to the correlation between the popularization of the internet and the growth of
} counterpublics, see Downey and Fenton (2003). 
Inspired by the Canadian 'SlutWalk', marches appeared all over Brazil between 2011 and 2013, and images of topless protesters, as well as disruptive performances staged by cultural collectives breaking saints and introducing crucifixes in the anus, flooded the traditional media and social media provoking reactions of shock.

Together with images coming from the Brazilian SlutWalks there was also a dissemination of others images, captured in LGBT Parades, such as a man dressed as Jesus Christ kissing another man and of a transsexual woman tied to a cross. In addition to the shock coming from progressive measures in the institutional arena, conservatives also felt attacked in civil society, as shown by Flávio Bolsonaro and Olavo de Carvalho in the same 2012 'live':

Flávio Bolsonaro: these manifestations today are the decadence of the human being. Television showed what the Gay Parade of São Paulo is, it is frightening, it is explicit sex in open air.

Olavo de Carvalho: Why do they do this? They could have defended their cause in a discrete, tranquil manner, showing gays to be well behaved people, why do they not do so? Why do they choose the contrary? 'Why choose scandal? Why choose this disrespectful carnival?' Because they know that this will 'shock' the religious and evangelicals and that these guys will have an emotional reaction, they will attack homosexualism [sic]. So, what do they do? 'Look, homophobia!' They use this as proof of homophobia, and the evangelicals and Catholics fall for this trick. They end up in a crusade against homosexualism. This is crap, my son, homosexualism exists since the fall of Adam, and you will not end it, what we have to fight against is this legislation which exists, and not homosexualism itself. This is rubbish. Also because there is this wonderful site called 'right-wing gays', and they denounce all this stuff, that there is a homophobic persecution, so these people are on our side, and I believe that the majority of gays will be on our side and that they understand the constitutive lie of this (left) movement and the psychotic ambitions of these people (BOLSONARO, 2012) (emphasis added).

Right-wing counterpublicity also gained supporters in political and business realms when the presidential candidacy of Jair Bolsonaro began to become a reality. In the midst of Rousseff's impeachment protests, demonstrators began to adopt Bolsonaro as their first option for the 2018 presidential elections. As Bolsonaro and his sons became better known in the discursive arenas attended by members of the emerging new right the dissemination of pro-Bolsonaro counterpublics accelerated. This was due both to the relative facility in triggering and mobilizing subjectivities taking into account the naturalization of domination, especially regarding gender and sexuality, as well as to the strengthening of 
Bolsonaro's presidential candidacy in the midst of Rousseff's impeachment protests, permeated by anti-Workers Party, anti-corruption, and anti-politics discourses (ORTELLADO; GALLEGO, and MORETTO, 2016; TELLES, 2016).

By incorporating all of these elements in its rhetoric, in addition to the lawand-order discourse, which responded both to insecurity in relation to criminality, and to the 'progressive shock', Bolsonaro began to rise as a new political force. Known for his controversial and disruptive discourse, the former army captain soon received the nickname 'Bolsomito' (Bolso-myth), in reference to his 'trolling', meaning that he could put an end to an argument in an way that left other people unable to react, which became popular on the internet in the middle of the dynamics created by publics and counterpublics. However, pro-Bolsonaro counterpublicity is, as a rule, much more radical than a regular 'trolling', due to his frequent exaltation of army Colonel Carlos Brilhante Ustra, a known torturer during the military dictatorship.

In this sense, it is possible to highlight two high points in the pro-Bolsonaro counterpublicity before his victory at the ballot box. The first is the tribute to Ustra made by Jair Bolsonaro in Congress during the vote for Rousseff's impeachment, when he declared: "In the memory of Colonel Carlos Alberto Brilhante Ustra, Dilma Rousseff's great fear6, I salute the army of Caxias, the Armed Forces, Brazil above everything, and God above everything, my vote is yes" (BARBA and WENTZEL, 2016). The second occurred in the middle of the 2018 electoral campaign, when Carlos Bolsonaro (son of Jair Bolsonaro) shared on his Instagram 'Stories' an image mocking the anti-Bolsonaro campaign organized by groups of women on social media known as \#EleNão. The photo, shared with the title "parents who cry in the shower!"7, made reference to a scene of torture and showed a bloody man, with his

\footnotetext{
6When younger Dilma Rousseff was a member of the guerilla group 'Vanguarda Armada Revolucionária Palmares' (VAR-Palmares), founded in 1969, aimed at overthrowing the dictatorship and led by a deserter from the military, Carlos Lamarca. At the time, due to her involvement with the organization, Rousseff was arrested and subjected to sessions of torture under the command of Colonel Carlos Alberto Brilhante Ustra, an officer from an intelligence and repression group subordinated to the army, the Information Operations Detachment - Center of Internal Defense Operations (DOI-CODI).

${ }^{7}$ Available at <https://brasil.elpais.com/brasil/2018/09/26/politica/1537997982_557864.html>. Accessed on April, 03, 2021.
} 
head inside a plastic sack, his mouth open, and the name of the movement written on his bare chest ${ }^{8}$.

\section{Bolsonaro and the dominant counterpublicity}

The dissemination of counterpublics was central for the development of counter-discourses aligned both with the emerging right and with 'Bolsonarismo' (ROCHA, 2021). However, after the 2018 elections, there was a normalization process of determined right-wing counterpublics, which moderated the performative radicality of its discourses, taking into account, for example, the action of certain political actors who later ended up disassociating themselves from 'Bolsonarismo'.

However, the hardcore of 'Bolsonarismo' did not go through any process of normalization, continuing to use counterpublicity as a radical counter-hegemonic political strategy in a conscious form. This can occur to the extent that a shared perception is continually fostered among the members who participate in certain discursive arenas that their discourse is blocked, silenced, despised, or even ridiculed in central arenas, understood by them as 'the system' or 'the establishment', and that the manifestation of their world-views and way of life are under an imminent threat, despite the rise to power of their political representatives.

The YouTube channel entitled 'Brasileirinhos' is very representative of such a perception. Since December 2017 the duo responsible for its content, composed of a young man dressed as a clown and another using a cat mask, produced avant-garde satirical videos and podcasts with a conservative content, in which they defended the arguments of Olavo de Carvalho and the Bolsonaro administration. Both assumed that in defending Christian and traditional values they were fighting the system, meaning that dialogues with either the traditional right or those who defended progressive agendas would be impossible from the start, as announced in the mini-documentary 'Catarsy' ${ }^{9}$, broadcast in 2019:

\footnotetext{
8The impacting image and the reaction of leftwing politicians can be seen at <https://ultimosegundo.ig.com.br/politica/2018-09-26/filho-de-bolsonaro-tortura.html>.

9The minidocumentary can be found at the link: <https://www.youtube.com/ watch?v=P4Q63c10kuw\&t=962s $>$.
} 
The 'gravatinhas' [bowties] of the right want an anodyne world of ideas, a democratic rule of law and a plurality of ideas, while the dream of the left is to destroy everything you love, everything you respect. Do you think this deserves your passionate defense? If you are having to debate your ideas, you have already lost, you just don't know it. For example, abortion is not an issue to be discussed, you have to spit in the abortionist's face and that is it. If you admit that this is a question for debate you have already lost. The day is coming when the most rational and coherent response that it will be suitable to these opinions is to stuff two fingers down your throat and barf on the shoes of those speaking to you (CATARSY, 2019).

While on the one hand, 'Bolsonarismo' currently holds the federal executive power of the country, and thus possesses a very important potential for hegemonic construction and discursive domination, like its social influence during the crisis of the COVID-19 pandemic (ROCHA; RIBEIRO, and MEDEIROS, 2020). However at the same time, it seeks to enter into constant shock with other discursive arenas, within and outside the state, with the purpose of keeping his supporters constantly mobilized. In this way there is a paradoxical phenomenon that we call: 'dominant counterpublicity'.

The possibility of a counterpublic becoming dominant is exactly what separates the subaltern counterpublics from non-subaltern counterpublics, like right-wing counterpublics. Finally, to the extent that values related to structures of domination which are still active, despite the ending of specific political regimes like the monarchy and military dictatorship in the case of Brazil -, its potential to establish a new social order once in power is much greater in comparison with subaltern counterpublics, which propose a transformation of the order which is not anchored on the maintenance or the return to traditional values, but on their transgression and subversion oriented towards emancipation (GOMES, 2018).

However, it is possible to say that there are important differences in relation to the use of dominant counterpublicity, considering both the right of free speech and the position occupied by those who utilize this discursive strategy. During the Bolsonaro administration, the president and his sons used counterpublicity several times, especially making eschatological references and using bad language with the press, but some of his supporters were punished for crossing the tenuous line which divide the acceptance of counterpublicity as part of the democratic exercise from direct attacks on the rule of law. 
In January 2020, for example, Roberto Alvim, Secretary of Culture, was exonerated for giving a speech containing phrases that were similar to the ones used by Joseph Goebbels, Adolf Hitler's propaganda minister and an idealizer of Nazism. In the speech given by Goebbels it was stated that "German art in the next decade will be heroic" and "imperative", while in Alvim's speech it was announced that "Brazilian art in the next decade will be heroic" and "imperative"10, causing reactions of shock and hostility in dominant publics. At the time, Alvim argued that the similarity was only 'rhetorical', however, according to the historians Jorge Paulino and Igor Rocha (2020), it was also possible to find a flagrant aesthetic similarity between the two:

The similitudes appear not only in parts of the discourse, but also in the background music - Lohengrin, a Richard Wagner opera, Hitler's favorite composer - and the actual mounting of the scene. As a 'man of the theater', Alvim knows how to compose scenarios. The framing of the commander, the position of the enunciator, the Jesuit cross: nothing is there by chance. The comparison of the images destroys the justification - given by the secretary after the disastrous repercussion - that it was nothing more than a coincidence (PAULINO and ROCHA, 2020) ${ }^{11 .}$

In this way, as Bolsonaro stated at the time, it became impossible for Alvim to remain in his position. In addition to the dismissal of the minister, the president apologized to the Jewish community and stated that he "repudiated totalitarian and genocidal ideologies, as well as any type of reference to them"12. The following year another of Bolsonaro's loyal supporters crossed the same line. Addressing himself on YouTube to the members of the Federal Supreme Court in a discourse permeated by cursing, profanity, and threats, Congressman Daniel Silveira was arrested in flagrant delicto' and his detention was confirmed by a majority of the Federal

${ }^{10}$ The pronouncement of the former secretary of culture can be seen at <https://www.youtube.com/watch?v=3lycKFW6ZHQ>.

${ }^{11}$ Comments available at <https://entendendobolsonaro.blogosfera.uol.com.br/2020/01/17/ terrivel-semelhanca-diz-historiador-da-arte-sobre-discurso-de-alvim/>.

12Declaration available at <https://www1.folha.uol.com.br/ilustrada/2020/01/bolsonarocomenta-polemica-de-discurso-nazista-e-diz-repudiar-ideologias-totalitarias-e-genocidas-comoo-nazismo-e-o-comunismo.shtml>. 
Congress, who decided that his conduct was an attack on democracy and on the democratic rule of law ${ }^{13}$.

Similar to Roberto Alvim, who claimed to have only committed a 'rhetorical' mistake, Silveira is said to had confessed to a party colleague, Congressman Bibo Nunes, who knew he would be arrested, but this was his 'style'. Nunes, in turn, stated that, like Silveira, he had demanded the removal of three STF judges but had not suffered any sort of punishment because, according to his own words, he was: "arguing without calling anyone this or that. There are ways of doing this. And he (Daniel Silveira) has this style"14. Again this points to the problematization of counterpublicity as a discursive strategy.

\section{Final considerations}

Counterpublics have two central dimensions: an ambivalent one and a paradoxical one. In relation to its ambivalence, it is possible to say that counterpublics stimulate a potential for the democratization of the dominant public sphere by pointing to the absence of plurality in the public debate and calling attention to social suffering which is little or not at all thematized by dominant publics (GOMES, 2018; HOCHSCHILD, 2016), ${ }^{15}$ but, at the same time, also stimulate sociocultural fragmentation and sociopolitical polarization.

Political polarization happens because counterpublics operate with a logic that there are only political enemies to be destroyed, and not political adversaries who can be coopted, convinced, or temporarily defeated. For the members of counterpublics the impossibility of debate lies in the perception that their enemies always act in a malicious, cruel, and psychopathic manner, are perverted, 'fascists', do not have humanity or rationality, or are victims of some sort of 'brain washing'

\footnotetext{
${ }^{13}$ The video can no longer be watched because YouTube removed it, alleging a violation of its policy on harassment and bullying. However, the transcription of the deputy's words can be read at $<$ https://www.poder360.com.br/justica/leia-a-transcricao-do-que-disse-daniel-silveira-e-o-quelevou-o-stf-a-prende-lo/>.

${ }^{14}$ Declaration available at <https://www.bol.uol.com.br/noticias/2021/02/19/daniel-silveiradisse-a-deputado-vou-ser-preso-nao-tem-problema.htm>.

${ }^{15}$ Gomes (2018) thematizes suffering related to gender violence through an analysis of the SlutWalk protests in Rio de Janeiro, Brazil, while Hochschild (2016) highlights feelings of anger and inferiority in her study of 'Tea Party' enthusiasts in Louisiana, in which a supporter of the movement says to her: "The liberals think that Southerners who believe in the Bible are ignorant, backwards, rednecks, losers. They think that we are racist, sexist, homophobic, and perhaps fat".
} 
which has indoctrinated them to defend malign ideas, making any rational debate of ideas impossible.

The paradoxical nature of counterpublics lies in their relationship with conflictuality. Counterpublics not only establish a conflict between the dominant cultural horizon and an alternative horizon, but also allow the conflict to be named as they voice their own utopia for the reorganization of public life (WARNER, 2002). Generally speaking, dominant publics work with the naturalization of their own cultural horizon and, thus, perpetuate the domination of their codes, performances, ideas, and structures, since they present themselves as consensual and free from any conflict. Counterpublicity denaturalizes this false consensus; but its paradoxical dimension relies on the difficulty of escaping pure conflictuality and fabricating new consensuses that are more inclusive and more reflexive ${ }^{16}$.

The actions of Jair Bolsonaro and his sons in government are a paradigmatic example of pure conflictuality: they betray and abandon allies, as Bolsonaro did when he abandoned the party elected; sabotage and impede new consensus from being formed, since this would betray the principle of counterpublicity; and hinder the construction of a social solidarity, even in times of a pandemic crisis. Bolsonaro's only goal is to demolish the foundations of dominant publics. He seeks to naturalize his own extremism, by moving the cultural horizon increasingly to the right (NUNES, 2020), and by promising a future authoritarian political regime for radicalized groups, which are also abandoned to their own luck if they threaten the permanence of 'Bolsonarismo' in power.

Dominant counterpublicity, thus, has a hybrid and unstable nature and seems to point to various political outcomes. If pro-Bolsonaro counterpublicity is weakened, other publics, on the left and/or the right, can strengthen themselves. However, if pro-Bolsonaro counterpublics become stronger, this can enact the beginning of a historical transition to a new authoritarian regime in Brazil,

\footnotetext{
16If we are not mistaken, this fabrication of new consensus is the normative horizon of Fraser's theory of the public sphere: the transformation of the discursive arenas of subaltern social groups as weak publics into strong publics, pushing the dominant public sphere in the direction of greater inclusion and reflexivity (FRASER, 1997). A process analogous to this occurred in Brazil with the 1988 constitutional pact; for this reason, we have interpreted this historical tendency as the emergence of a post-bourgeois public sphere, now in decline.
} 
called by the members of these counterpublics a 'cultural revolution'17. It requires not only the destruction of institutions which allow the reproduction of the cultural horizon, related to the democratic pact established by the 1988 Constitution, but also the creation of new institutions capable of normalizing their counter-discourses and making them hegemonic through a new configuration of Brazilian political culture.

Translated by Eoin Portela

Submitted on March 03, 2021

Accepted on April 06, 2021

\section{References}

ARAÚJO, Ernesto (2021) For a liberal-conservative reset. Available at $<$ https://www.metapoliticabrasil.com/post/for-a-liberal-conservative-reset $>$. Accessed on February, 27, 2021.

BARBA, Mariana Della and WENTZEL, Marina (2016), Discurso de Bolsonaro deixa 'ativistas' estarrecidos e leva $\mathrm{OAB}$ a pedir sua cassação. Available at $<$ https://www.bbc.com/portuguese/noticias/2016/04/160415_bolsonaro_ongs_ $o a b \_m d b>$. Accessed on April, 03, 2021.

BOLSONARO, Flávio (2012), YouTube Channels. Available at $<$ https://www.youtube.com/watch?v=Cb0JGA80iLo $>$. Accessed on April, 03, 2021.

BUTLER, Judith (2006), Philosophical encounters of the third kind. Documentary. YouTube. Available at <https://www.youtube.com/watch?v=dDQ_-Gvyj18>. Accessed on February, 27, 2021.

CARVAlHO, Olavo de (2012), True Outspeak, № 293, December, 05, 2012. Available at <https://podcasts.apple.com/br/podcast/true-outspeak-293despedida /id1493069763?i=1000460978905>. Accessed on April, 03, 2021.

CARVALHO, Olavo de (2009), A revolução globalista. Digesto Econômico. Available at <https://olavodecarvalho.org/a-revolucao-globalista/>. Accessed on February, 25, 2021.

CELIKATES, Robin (2015), Digital publics, digital contestation: a new structural transformation of the public sphere? In: Transformations of democracy. Edited by CELIKATES, Robin; KREIDE, Regina, and WESCHE, Tilo. London: Rowman \& Littlefield. pp. 159-176.

${ }^{17} \mathrm{Cf} . \quad<$ https://politica.estadao.com.br/noticias/geral,weintraub-ajuda-o-governo-narevolucao-cultural-diz-eduardo-bolsonaro,70003215525>. 
COLLINS, Patricia Hill (2009), Black feminist thought: knowledge, consciousness, and the politics of empowerment. New York: Routledge. 384 pp..

DOWNEY, John and FENTON, Natalie (2003), New media, counter publicity and the public sphere. New Media Society. Vol. 05, № 02, pp. 185-202.

FRAGOSO, Suely (2006) Eu odeio quem odeia... Considerações sobre o comportamento dos usuários brasileiros na 'tomada' do Orkut. E-Compós. Vol. 06. Available at <https://doi.org/10.30962/ec.89>. Accessed on April, 03, 2021.

FRASER, Nancy (1997), Rethinking the public sphere: a contribution to the critique of actually existing democracy. In: Justice interruptus: critical reflections on the 'postsocialist' condition. New York/London: Routledge. pp. 56-80.

GOMES, Carla de Castro (2018), Corpo, emoção e identidade no campo feminista contemporâneo brasileiro: a Marcha das Vadias do Rio de Janeiro. Doctoral thesis. Instituto de Filosofia e Ciências Sociais. Programa de Pós-Graduação em Sociologia e Antropologia. Universidade Federal do Rio de Janeiro.

HABERMAS, Jürgen (1989), The structural transformation of the public sphere: an inquiry into a category of Bourgeois society. Cambridge: The MIT Press. 328 pp..

HOCHSCHILD, Arlie Russell (2016), Strangers in their own land. New York: The New Press. 368 pp..

MEDEIROS, Jonas Marcondes Sarubi de (2017), Movimentos de mulheres periféricas na Zona Leste de São Paulo: ciclos políticos, redes discursivas e counterpublics. Doctoral thesis. Faculdade de Educação. Universidade Estadual de Campinas.

MEDEIROS, Jonas and FANTI, Fabiola (2019), Recent changes in the Brazilian feminist movement: the emergence of new collective actors. In: Socio-Political dynamics within the crisis of the left: Argentina and Brazil. Edited by FERRERO, Juan Pablo; NATALUCCI, Ana, and TATAGIBA, Luciana. London: Rowman \& Littlefield. pp. 221-242.

NAGLE, Angela (2017) Kill all normies: online culture wars from 4chan and Tumblr to Trump and the alt-right. London: John Hunt Publishing. 136 pp..

NUNES, Rodrigo (2020), Alvim errou a mão na trollagem nazi inspirada na direita dos EUA. Folha de São Paulo. January, 21, 2020.

ORTELlADO, Pablo; GALlEGO, Esther Solano, and MORETTO, Márcio (2017), 'Guerras culturais' e 'populismo anti-petista' nas ruas de 2017. Notas-FriedrichEbert-Stiftung Brasil. № 10, pp. 01-08. 
PAULINO, Jorge and ROCHA, Igor (2020), "Terrível semelhança": historiadores analisam vídeo de Alvim. Available at $<$ https://entendendobolsonaro.blogosfera.uol.com.br/2020/01/17/terrivelsemelhanca-diz-historiador-da-arte-sobre-discurso-de-alvim/>. Accessed on April, 03, 2021.

ROCHA, Camila (2021), The new Brazilian right and the public sphere. Mecila Working Paper Series., № 32. São Paulo: The Maria Sibylla Merian International Centre for Advanced Studies in the Humanities and Social Sciences Conviviality-Inequality in Latin America. Available at <http://dx.doi.org/10.46877/rocha.2021.32>. Accessed on April, 03, 2021.

ROCHA, Camila and MEDEIROS, Jonas (2020), Vão todos tomar no...: a política do choque e a esfera pública. Horizontes ao Sul. Available at $<$ https://www.horizontesaosul.com/single-post/2020/04/27/VAO-TODOSTOMAR-NO-A-POLITICA-DO-CHOQUE-E-A-ESFERA-PUBLICA>. Accessed on February, 27, 2021.

ROCHA, Camila; RIBEIRO, Márcio Moretto, and MEDEIROS, Jonas (2020), O counterpublic bolsonarista e o negacionismo da pandemia. Blog da Revista Novos Estudos Cebrap. Available at <http://novosestudos.com.br/ocontrapublico-bolsonarista-e-o-negacionismo-da-pandemia/>. Accessed on February, 27, 2021.

TELLES, Helcimara (2016), A Direita vai às r. uas: o antipetismo, a corrupção e democracia nos protestos antigoverno. Ponto \& Vírgula. Vol. 19, pp. 97-125.

THIMSEN, A. Freya (2017), Did the Trumpian counterpublic dissent against the dominant model of campaign finance? Javnost - The Public. Vol. 24, № 03, pp. 267-283.

WARNER, Michael (2002), Publics and counterpublics. New York: Zone Books. 336 pp.. 